\title{
Article
}

\section{Garpenbergite, $\mathrm{Mn}_{6} \square \mathrm{As}^{5+} \mathrm{Sb}^{5+} \mathrm{O}_{10}(\mathrm{OH})_{2}$, a new mineral related to manganostibite, from the Garpenberg $\mathrm{Zn}-\mathrm{Pb}-\mathrm{Ag}$ deposit, Sweden}

\author{
Dan Holtstam ${ }^{\star \star}$ (D), Luca Bindi ${ }^{2}$ (D), Hans-Jürgen Förster ${ }^{3}$ (D), Andreas Karlsson ${ }^{1}$ (D) and Kjell Gatedal ${ }^{4}$ \\ ${ }^{1}$ Department of Geosciences, Swedish Museum of Natural History, Box 50007, SE-104 05 Stockholm, Sweden; ${ }^{2}$ Dipartimento di Scienze della Terra, Università degli \\ Studi di Firenze, Via G. La Pira 4, 50121, Firenze, Italy; ${ }^{3}$ Helmholtz Centre Potsdam GFZ German Research Centre for Geosciences, Section Geoenergy, 14473 \\ Potsdam, Germany; and ${ }^{4}$ Baldersgatan 21, SE-713 32 Nora, Sweden
}

\begin{abstract}
Garpenbergite is a new mineral (IMA2020-099) from the Garpenberg Norra mine, Hedemora, Dalarna, Sweden. It occurs with carlfrancisite and minor stibarsen, paradocrasite and filipstadite in a fractured skarn matrix of granular jacobsite, alleghanyite, kutnohorite and dolomite. Crystals are short-prismatic, up to $1.5 \mathrm{~mm}$ in length. They have a blackish to greyish brown colour, and are lustrous semi-opaque, with brown streak. Garpenbergite is brittle, with an uneven to subconchoidal fracture. Cleavage is distinct on $\{010\}$. Hardness $\approx 5$ (Mohs) and $\mathrm{VHN}_{100}=650(40) . D_{\text {calc }}=4.47(1) \mathrm{g} \cdot \mathrm{cm}^{-3}$, overall $n_{\text {calc }}=1.85$. Maximum specular reflectance values $(\%)$ obtained are $9.2(470 \mathrm{~nm}), 9.1(546$ $\mathrm{nm})$, $9.0(589 \mathrm{~nm})$ and $8.9(650 \mathrm{~nm})$. The empirical chemical formula of garpenbergite, based on electron microprobe data, is $\left(\mathrm{Mn}_{3.97}^{2+} \mathrm{Mg}_{1.48} \mathrm{Mn}_{0.26}^{3+} \mathrm{Zn}_{0.29}\right)_{\Sigma 6.00}\left(\mathrm{As}_{0.89} \mathrm{Fe}_{0.04}^{3+} \mathrm{Mn}_{0.06}^{3+} \mathrm{Si}_{0.01}\right)_{\Sigma 1.00}\left(\mathrm{Sb}_{0.98} \mathrm{Fe}_{0.02}\right)_{\Sigma 1} \mathrm{O}_{10}\left[(\mathrm{OH})_{1.99} \mathrm{Cl}_{0.01}\right]_{\Sigma 2.00}$. The five strongest Bragg peaks in the powder X-ray diffraction pattern $[d, \AA(I, \%)(h k l)]$ are $3.05(30)(002), 2.665(100)(161), 2.616(40)(301), 2.586(25)(251)$ and 1.545 (45) (462). The orthorhombic unit-cell dimensions (in $\AA$ ) are $a=8.6790(9), b=18.9057(19)$ and $c=6.1066(6)$, with $V=1001.99(18) \AA^{3}$ for $Z=4$. The crystal structure was refined from single-crystal X-ray diffraction data in the space-group $I b m m$ to $R_{1}=3.7 \%$ for 957 reflections. Garpenbergite, ideally $\mathrm{Mn}_{6} \mathrm{As}^{5+} \mathrm{Sb}^{5+} \mathrm{O}_{10}(\mathrm{OH})_{2}$, is isostructural with manganostibite, $\mathrm{Mn}_{7} \mathrm{AsSbO}_{12}$, but possesses a cation vacancy ( $\square$ ) at an octahedrally coordinated structural site; the two minerals are thus related by the exchange $\mathrm{Mn}^{2+}+2 \mathrm{O}^{2-} \rightarrow \square+2(\mathrm{OH})^{-}$. The presence of hydroxyl groups is supported by vibration bands at 3647 and $3622 \mathrm{~cm}^{-1}$ in the Raman spectrum of garpenbergite and by bond-valence considerations.
\end{abstract}

Keywords: garpenbergite, new mineral, manganostibite, carlfrancisite, crystal structure, cubic close packing, Raman spectrum, skarn, Garpenberg, Sweden

(Received 30 November 2021; accepted 11 January 2022; Accepted Manuscript published online: 21 January 2022; Associate Editor: Daniel Atencio)

\section{Introduction}

Metal mining at Garpenberg, Hedemora, Dalarna (Dalecarlia), Sweden, has been described in annals since the fourteenth Century, however recent studies of Holocene lake-sediment records in the area indicate that small-scale extraction of copper occurred earlier, in the pre-Roman iron age, from ca. 375 B.C. (Bindler et al., 2017). Mining is still active; the current business has been operated since 1957 by Boliden $\mathrm{AB}$, which presently produces $3 \mathrm{Mt}$ of ore per year. The grades are $0.5 \mathrm{~g} / \mathrm{t} \mathrm{Au}, 70-160 \mathrm{~g} / \mathrm{t}$ $\mathrm{Ag}, 0.1 \% \mathrm{Cu}, 2 \% \mathrm{~Pb}$ and $3-4 \% \mathrm{Zn}$ (Bolin et al., 2003; Tiu et al., 2021).

The sample containing the new mineral presented here was collected in situ at the $900 \mathrm{~m}$ level of the Garpenberg Norra mine $\left(60^{\circ} 20^{\prime} \mathrm{N}, 16^{\circ} 13.5^{\prime} \mathrm{E}\right)$, where various exotic skarn mineral

\footnotetext{
*Author for correspondence: Dan Holtstam. Email: dan.holtstam@nrm.se Cite this article: Holtstam D., Bindi L., Förster H.-J., Karlsson A. and Gatedal K. (2022) Garpenbergite, $\mathrm{Mn}_{6} \square \mathrm{As}^{5+} \mathrm{Sb}^{5+} \mathrm{O}_{10}(\mathrm{OH})_{2}$, a new mineral related to manganostibite, from the Garpenberg $\mathrm{Zn}-\mathrm{Pb}-\mathrm{Ag}$ deposit, Sweden. Mineralogical Magazine 86, 1-8. https:// doi.org/10.1180/mgm.2022.6
}

assemblages have been noted to exist (Eriksson and Kalinowski, 2001; Holtstam et al., 2001; Holtstam, 2002; Kolitsch and Holtstam, 2002; Nysten, 2003). Garpenbergite was first spotted by one of the authors (K.G.) in a polished section. Preliminary chemical data suggested a close relationship to manganostibite, ideally $\mathrm{Mn}_{7} \mathrm{AsSbO}_{12}$, a rare mineral first described by Igelström (1884) from the Nordmark ore field, Filipstad, Värmland, Sweden. A subsequent Raman study, however, indicated a distinct new species (cf. Holtstam, 2021).

The name of the mineral is for the place of discovery, Garpenberg. In the Middle Ages, 'garp' was the colloquial word in Swedish for a German person. The term here refers to the fact that the Swedish Crown recruited German miners at the time in order to increase know-how and develop regulations in the kingdom's growing mining industry (Carlberg, 1879).

The new mineral species and its name (symbol Grp) have been approved by the Commission on New Minerals, Nomenclature and Classification of the International Mineralogical Association (IMA2020-099, Holtstam et al., 2021). The holotype material is deposited in the type mineral collection of the Department of

(c) The Author(s), 2022. Published by Cambridge University Press on behalf of The Mineralogical Society of Great Britain and Ireland. This is an Open Access article, distributed under the terms of the Creative Commons Attribution licence (http://creativecommons.org/licenses/by/4.0/), which permits unrestricted re-use, distribution and reproduction, provided the original article is properly cited. 
Geosciences, Swedish Museum of Natural History, Box 50007, SE-10405 Stockholm, Sweden, under collection number GEO-NRM \#20010351 (specimen and polished section) and \#20200040 (polished section).

\section{Occurrence}

Garpenberg is situated in the northern part of the Palaeoproterozoic Bergslagen ore region in central Sweden, where numerous stratabound sulfide and $(\mathrm{Fe} \pm \mathrm{Mn})$ oxide deposits are hosted by 1.9-1.8 $\mathrm{Ga}$ felsic volcanic rocks and interlayered limestones, with enveloping siliciclastic sedimentary rocks and intruding Svecokarelian plutons (Stephens and Jansson, 2020). The Garpenberg polymetallic Zn$\mathrm{Pb}-\mathrm{Ag}-(\mathrm{Cu}-\mathrm{Au})$ sulfide deposit stretches about seven $\mathrm{km}$ in a SW-NE direction, and comprises several ore bodies, mainly confined to a marble horizon. Significant mineralisation also occurs in adjacent metavolcanic rocks. At a stratigraphically lower level, several magnetite skarn ores are present. The rock units have experienced pervasive hydrothermal alteration proximal to the ore bodies (Vivallo 1985; Allen et al., 2003), metamorphism and polyphase deformation. Most or all of the Fe oxide and complex sulfide ores in the Garpenberg area formed within the time span 1895-1890 Ma during a syn-volcanic event (Jansson and Allen, 2011). Peak metamorphic conditions for the deposit are estimated at $T \geq 550^{\circ}$ $\mathrm{C}$ and $P<0.35 \mathrm{GPa}$ imposed around $1.85 \mathrm{Ga}$ (Vivallo 1985).

The marbles at Garpenberg host enclaves of sporadic low-S, $\mathrm{Mn}-\mathrm{Zn}-\mathrm{Pb}-\mathrm{Ba}-\mathrm{Sb}-\mathrm{As}$ mineralisation, reminiscent of both Långban (Holtstam and Langhof, 1999; Holtstam and Mansfeld, 2001) and Franklin-Sterling Hill (Dunn, 1995; Peck et al., 2009) types of deposits. The genetic relation to the main sulfide ores and skarns at Garpenberg remains unclear.

The size of the sample containing the new mineral is small, ca. $2 \mathrm{~cm} \times 1.5 \mathrm{~cm} \times 1 \mathrm{~cm}$. Garpenbergite occurs in a filled fracture together with mainly carlfrancisite (Fig. 1). Minor stibarsen and paradocrasite appear in fractures of garpenbergite. Filipstadite has been observed in a few cases, as tiny overgrowths on garpenbergite. The rock matrix consists of granular jacobsite, alleghanyite, kutnohorite and dolomite. Following a brittle-deformation event, garpenbergite probably crystallised from a locally mobilised, As-Sb-rich fluid. Redox conditions were apparently varying, as evidenced by the presence of arsenate, arsenite and arsenide mineral species in the same fissure mineralisation. The mineral-forming episode is probably coeval with the transition from ductile to brittle deformation that occurred in the area at $\sim 1.8-1.7 \mathrm{Ga}$ (Stephens and Jansson, 2020).

\section{Physical and optical properties}

The new mineral occurs as heavily fractured, short-prismatic (along [010]) and mostly subhedral crystals up to $1.5 \mathrm{~mm}$ in length. The macroscopic colour is blackish to greyish brown, the streak is light brown. Garpenbergite has a sub-adamantine to greasy lustre and is semi-opaque (translucent in thin splinters). The hardness is $\sim 5$ on the Mohs scale. The micro-indentation hardness $\left(\mathrm{VHN}_{100}\right)$, obtained by means of a Shimadzu type-M tester, is $650(6.37 \mathrm{GPa})$ based on ten measurements, giving a total range of 580-694. The shape of indentations are straight to slightly concave, with simple shell fractures (Jambor and Vaughan, 1990). Garpenbergite is brittle, with an uneven to subconchoidal fracture. Cleavage is distinct on $\{010\}$.

The density was not measured, because of current prohibition of heavy liquids; a calculated value of $4.47(1) \mathrm{g} \cdot \mathrm{cm}^{-3}$ was obtained based on the empirical formula and unit-cell volume from singlecrystal diffraction data (see below). Garpenbergite is nonmagnetic with respect to a neodymium hand magnet, and soluble in $30 \% \mathrm{HCl}(\mathrm{aq})$ at room temperature. No fluorescence was detected under ultra-violet light.

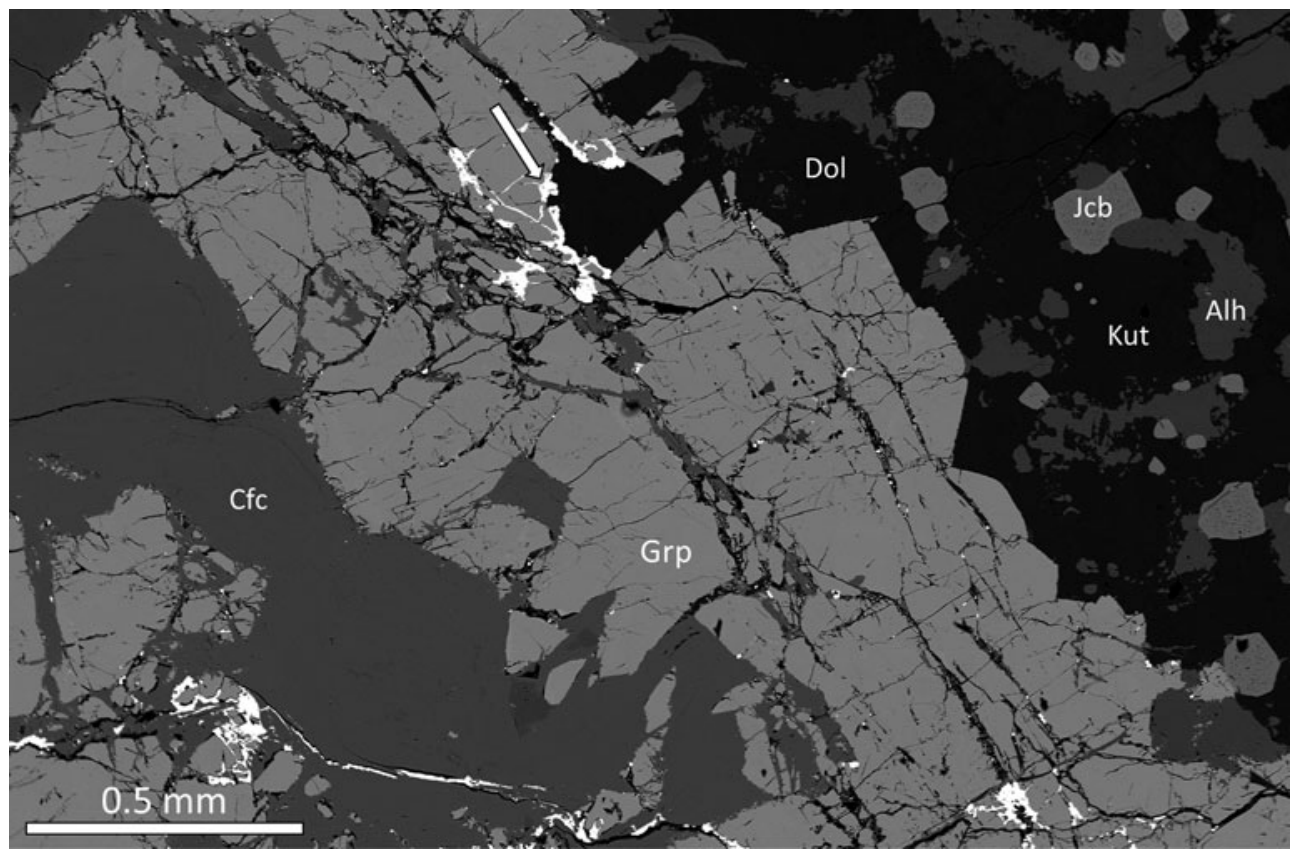

Fig. 1. Back-scattered electron scanning electron microscopy image of a polished section of the garpenbergite (Grp) type specimen, with carlfrancisite (Cfc), jacobsite (Jcb), alleghanyite (Alh), dolomite (Dol) and kutnohorite (Kut). The arrow points to one area (white) containing a fine intergrowth of stibarsen and paradocrasite. Sample GEO-NRM \#20200040. 
Table 1. Reflectance values (in \%; wavelengths recommended by the Commission on Ore Mineralogy in bold).

\begin{tabular}{llllll}
\hline$\lambda(\mathrm{nm})$ & $R_{2}$ & $R_{1}$ & $\lambda(\mathrm{nm})$ & $R_{2}$ & $R_{1}$ \\
\hline 400 & 9.50 & 8.93 & 560 & 9.02 & 8.49 \\
420 & 9.41 & 8.83 & 580 & 8.97 & 8.50 \\
440 & 9.30 & 8.73 & $\mathbf{5 8 9}$ & 8.96 & 8.47 \\
460 & 9.23 & 8.68 & 600 & 8.96 & 8.44 \\
$\mathbf{4 7 0}$ & 9.20 & 8.67 & 620 & 8.93 & 8.44 \\
480 & 9.17 & 8.66 & 640 & 8.88 & 8.47 \\
500 & 9.17 & 8.65 & $\mathbf{6 5 0}$ & 8.90 & 8.48 \\
520 & 9.04 & 8.54 & 660 & 8.93 & 8.48 \\
540 & 9.05 & 8.50 & 680 & 8.91 & 8.46 \\
$\mathbf{5 4 6}$ & 9.04 & 8.49 & 700 & 8.90 & 8.46 \\
\hline
\end{tabular}

The optical character in transmitted light could not be determined owing to strong absorption and high refraction of the crystals. The overall refractive index $(n)$ is calculated to 1.847 , using Gladstone-Dale constants listed by Mandarino (1981). In reflected polarised light, garpenbergite is grey, with no perceptible bireflectance or pleochroism. It is weakly to moderately anisotropic under crossed polars. Reflectance spectra were measured in air with an AVASPEC-ULS2048 $\times 16$ spectrometer connected to a Zeiss Axiotron UV-microscope $(10 \times / 0.20$ Ultrafluar objective), using a tungsten filament lamp $(100 \mathrm{~W})$ and a dichroic HNPB polaroid filter. Silicon carbide (Zeiss no. 846) was used as standard, and the annular measurement area was $\sim 0.1 \mathrm{~mm}$ in diameter on the sample surface. Results from the visible spectrum range (average of 100 scans, $100 \mathrm{~ms}$ integration time) are given in Table 1.

In comparison with the related manganostibite, garpenbergite is slightly more translucent, and has a lower overall reflectance.

\section{Raman spectroscopy}

A micro-Raman spectrum of garpenbergite (Fig. 2) was obtained from a crystal in the polished section on a LabRAM HR 800 spectrometer, using a $514 \mathrm{~nm}$ Ar-ion laser source at $<1 \mathrm{~mW}$ power, a Peltier-cooled $\left(-70^{\circ} \mathrm{C}\right) 1024 \times 256$ pixel CCD detector, a Olympus M Plan N 100×/0.9 NA objective and laser spot of ca. $3 \mu \mathrm{m}$. A 600 grooves/cm grating was used, and the spectral resolution is $\sim 1 \mathrm{~cm}^{-1}$. Peak positions were corrected against the Raman band at $789 \mathrm{~cm}^{-1}$ of a silicon carbide crystal. Instrument control and data acquisition (range $100-4000 \mathrm{~cm}^{-1}, 10 \mathrm{~s}$ exposure time in 20 cycles) were made with the LabSpec 5 software. Laser-induced degradation of the sample was not observed. A single crystal of manganostibite (from Igelström's type specimen, GEO-NRM \#18840177) was measured with the same settings for a comparison (Fig. 2).

Observable bands are at $3647,3622,1300,1020,818,791$ (shoulder), 695, 659, 620 (shoulder), 580, 541, 512, 482, 464, 339,259 and $233 \mathrm{~cm}^{-1}$. The two distinct Raman bands above $3600 \mathrm{~cm}^{-1}$ are related to $\mathrm{OH}$-stretching vibration modes. The strongest peak at $818 \mathrm{~cm}^{-1}$ (with shoulder at $791 \mathrm{~cm}^{-1}$ ) corresponds to stretching vibrations of the $\left[\mathrm{AsO}_{4}\right]^{3-}$ groups (Myneni et al., 1998). Bands in the region $695-620 \mathrm{~cm}^{-1}$ are attributable to the symmetric and antisymmetric stretching modes of $\mathrm{SbO}_{6}$ octahedra (cf. Guillén-Bonilla et al., 2014), whereas peaks at lower frequencies down to $\sim 450 \mathrm{~cm}^{-1}$ probably arises from the $\mathrm{Mn}(\mathrm{Mg})-\mathrm{O}$ stretching in tetrahedra and octahedra. Specifically, bands around $530 \mathrm{~cm}^{-1}$ could be attributed to octahedrally coordinated $\mathrm{Mn}^{2+}$ (Bernardini et al., 2021). In the spectrum of manganostibite, corresponding bands occur at similar positions (within $10-20 \mathrm{~cm}^{-1}$ ), with a clear exception for the $\mathrm{OH}$ vibration modes, which are absent.

\section{Chemical composition}

Preliminary energy-dispersion (EDS) X-ray measurements on a polished sample section showed $\mathrm{Mn}, \mathrm{Mg}, \mathrm{Sb}, \mathrm{As}, \mathrm{Zn}$ and $\mathrm{O}$ to be present in garpenbergite. The chemical composition was ultimately determined using a JEOL JXA 8230 electron microprobe operating in wavelength dispersive spectroscopy mode at $15 \mathrm{kV}$ and $20 \mathrm{nA}$, with a defocused beam size of $10 \mu \mathrm{m}$ (to minimise

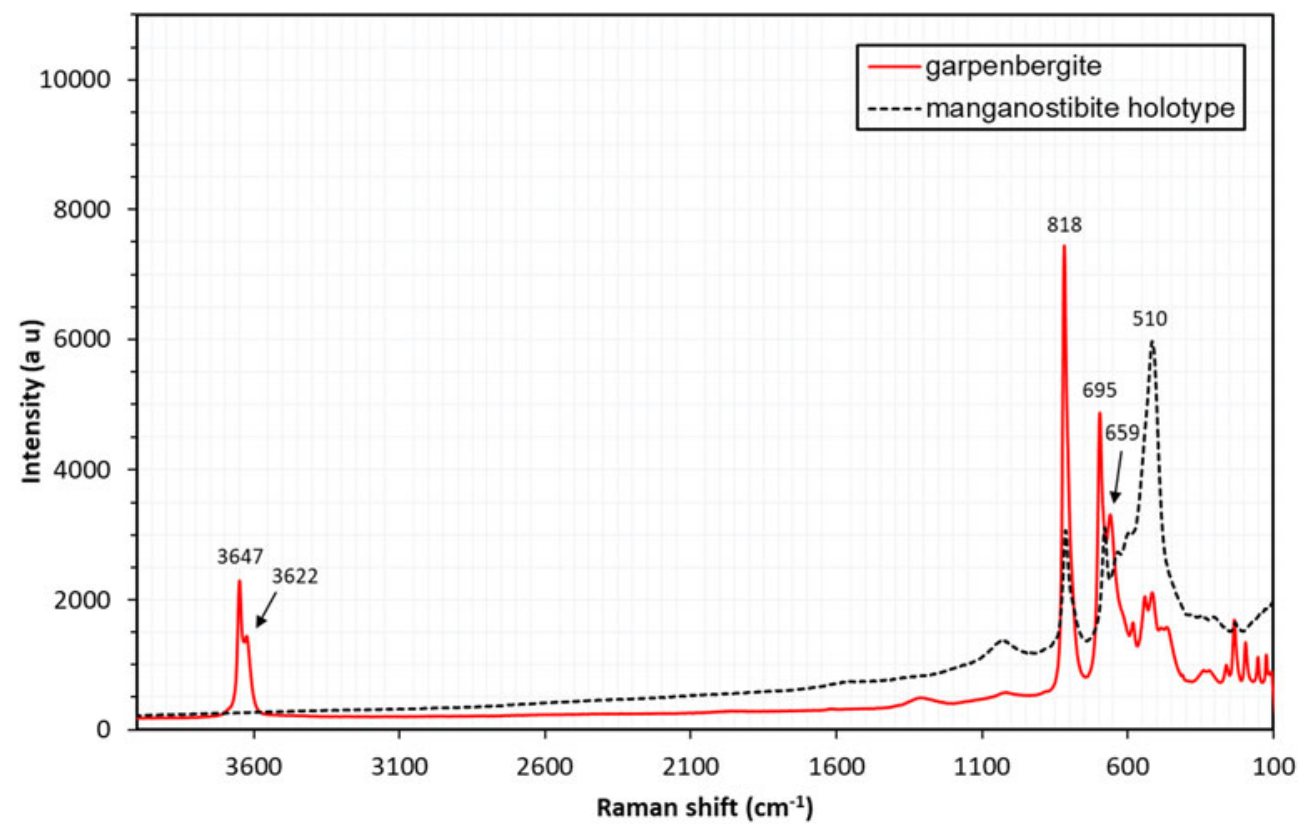

Fig. 2. Raman spectra of garpenbergite and manganostibite, obtained with a 514-nm laser. 
diffusion of elements mobile under the electron beam). Measurement time on peaks and background was 20 and $10 \mathrm{~s}$, respectively. Reference materials and measured lines were: rhodonite $(\mathrm{SiK} \alpha)$, orthoclase $(\mathrm{AlK} \alpha), \mathrm{Fe}_{2} \mathrm{O}_{3}(\mathrm{FeK} \alpha), \mathrm{MnTiO}_{3}(\mathrm{MnK} \alpha)$, diopside $(\mathrm{MgK} \alpha$ and $\mathrm{CaK} \alpha$ ), adamite (AsL $\alpha$ and $\mathrm{ZnK \alpha}$ ), InSb $(\mathrm{Sb} L \alpha)$, fluorite $(\mathrm{FK} \alpha)$ and tugtupite $(\mathrm{Cl} K \alpha)$. The number of spot analyses was 49 . The $\mathrm{H}_{2} \mathrm{O}$ content was not determined directly, because of scarcity of material. No $\mathrm{CO}_{2}$ was indicated by crystal structure refinements or spectroscopic data. The following elements were sought but found to be below detection: $\mathrm{Na}, \mathrm{Ca}, \mathrm{Al}$, $\mathrm{P}, \mathrm{V}$ and $\mathrm{F}$. The results of the analyses are given in Table 2. Associated carlfrancisite was also analysed (10 spots) at the same analytical conditions, and gave: $\mathrm{SiO}_{2}$ 8.41, $\mathrm{Al}_{2} \mathrm{O}_{3}$ 0.12, $\mathrm{Fe}_{2} \mathrm{O}_{3}$ 0.77, $\mathrm{MnO}$ 51.84, $\mathrm{MgO}$ 10.87, $\mathrm{CaO} 0.03, \mathrm{As}_{2} \mathrm{O}_{5}$ 18.23, $\mathrm{Sb}_{2} \mathrm{O}_{5}$ 0.06, $\mathrm{ZnO} 0.42, \mathrm{~F} 0.11, \mathrm{H}_{2} \mathrm{O}_{\text {calc }} 8.31$, total 99.17 (all in wt.\%).

The empirical formula of garpenbergite, calculated on the basis of eight cations and assuming - as inferred from crystalstructural features-As and $\mathrm{Sb}$ as pentavalent cations, and with the $\mathrm{Mn}^{2+} / \mathrm{Mn}^{3+}$ ratio adjusted to obtain overall electroneutrality, is $\left(\mathrm{Mn}_{3.97}^{2+} \mathrm{Mg}_{1.48} \mathrm{Mn}_{0.26}^{3+} \mathrm{Zn}_{0.29}\right)_{\Sigma 6.00}\left(\mathrm{As}_{0.89} \mathrm{Fe}_{0.04}^{3+} \mathrm{Mn}_{0.06}^{3+} \mathrm{Si}_{0.01}\right)_{\Sigma 1.00}$ $\left(\mathrm{Sb}_{0.98} \mathrm{Fe}_{0.02}\right)_{\Sigma 1.00} \mathrm{O}_{10}\left[(\mathrm{OH})_{1.99} \mathrm{Cl}_{0.01}\right]_{\Sigma 2.00}$. The ideal formula becomes $\mathrm{Mn}_{6}^{2+} \square \mathrm{As}^{5+} \mathrm{Sb}^{5+} \mathrm{O}_{10}(\mathrm{OH})_{2}$, which corresponds to (in wt.\%) $\mathrm{MnO}$ 59.10, $\mathrm{Sb}_{2} \mathrm{O}_{5}$ 22.44, $\mathrm{As}_{2} \mathrm{O}_{5}$ 15.96, $\mathrm{H}_{2} \mathrm{O}$ 2.50, total 100.00.

The empirical formula for associated carlfrancisite, based on 96 anions with $(\mathrm{OH}, \mathrm{F})=42$ atoms per formula unit (apfu) and $\mathrm{As}^{3+}=2$ apfu, is $\mathrm{Mn}_{3}^{2+}\left(\mathrm{Mn}_{30.42}^{2+} \mathrm{Mg}_{12.33} \mathrm{Zn}_{0.24} \mathrm{Ca}_{0.02}\right)_{\Sigma 43.01}\left(\mathrm{As}^{3+} \mathrm{O}_{3}\right)_{2}$ $\left(\mathrm{As}^{5+} \mathrm{O}_{4}\right)_{4}\left[\left(\mathrm{Si}_{0.80} \mathrm{As}_{0.11}^{5+} \mathrm{Fe}_{0.06}^{3+} \mathrm{Sb}_{0.02} \mathrm{Al}_{0.02}\right)_{\Sigma 1.01} \mathrm{O}_{4}\right]_{8}\left(\mathrm{OH}_{0.98} \mathrm{~F}_{0.02}\right)_{42}$.

\section{X-ray diffraction data and crystal-structure refinement}

Powder X-ray diffraction data (Table 3) were obtained with a Bruker D8 Venture diffractometer equipped with Photon III CCD detector and using copper radiation $(\mathrm{CuK \alpha}, \lambda=1.54138 \AA$ ), with $600 \mathrm{~s}$ of exposure; the detector-to-sample distance was $7 \mathrm{~cm}$. The program Apex3 (Bruker AXS Inc., 2016) was used to convert the observed diffraction rings to a conventional powder diffraction pattern. A least-squares refinement of the orthorhombic unit cell gave the following values: $a=8.6919(10) \AA, b=18.927(3) \AA$, $c=6.1110(6) \AA$ and $V=1005.3(1) \AA^{3}$ for $Z=4$.

A single-crystal $\mathrm{X}$-ray diffraction study was performed on a 55 $\mu \mathrm{m} \times 45 \mu \mathrm{m} \times 40 \mu \mathrm{m}$ crystal fragment (counterpart of the piece used to make polished section for electron probe analysis) using a Bruker D8 Venture diffractometer equipped with Photon III CCD detector, with graphite-monochromatised $\mathrm{MoK \alpha}$ radiation

Table 2. Chemical composition of garpenbergite (in wt.\% oxide).

\begin{tabular}{lrcr}
\hline Constituent & Mean & Range & $2 \sigma$ \\
\hline $\mathrm{SiO}_{2}$ & 0.11 & $0.05-0.20$ & 0.08 \\
$\mathrm{Fe}_{2} \mathrm{O}_{3}$ & 0.71 & $0.23-2.16$ & 0.75 \\
$\mathrm{MnO}_{\mathrm{Mn}} \mathrm{O}_{3}$ calc & 41.93 & $40.75-43.63$ & 1.10 \\
$\mathrm{MgO}_{\mathrm{As}} \mathrm{O}_{5}$ & 3.71 & $2.17-5.31$ & 1.36 \\
$\mathrm{Sb}_{2} \mathrm{O}_{5}$ & 8.89 & $7.98-9.27$ & 0.48 \\
$\mathrm{ZnO}_{\mathrm{H} O}$ & 15.15 & $13.92-16.02$ & 0.85 \\
$\mathrm{H}_{2}$ & 23.63 & $22.90-24.25$ & 0.45 \\
$\mathrm{Cl}$ & 3.55 & $3.32-3.86$ & 0.22 \\
$\mathrm{O} \equiv \mathrm{Cl}$ & 2.67 & $2.64-2.69$ & 0.02 \\
$\mathrm{Total}$ & 0.04 & $0.02-0.09$ & 0.02 \\
\hline
\end{tabular}

*Inferred from crystal structure, $(\mathrm{OH}+\mathrm{Cl})=2$ apfu.
Table 3. Powder X-ray diffraction data ( $d$ in $\AA$ ) for garpenbergite*.

\begin{tabular}{|c|c|c|c|c|}
\hline$I_{\text {calc }}$ & $I_{\text {obs }}$ & $d_{\text {calc }}$ & $d_{\text {obs }}$ & $h k l$ \\
\hline 47 & - & 9.4529 & - & 020 \\
\hline 14 & - & 7.8876 & - & 110 \\
\hline 22 & 15 & 5.0994 & 5.10 & 130 \\
\hline 27 & 25 & 4.9942 & 5.00 & 101 \\
\hline 5 & - & 4.7264 & - & 040 \\
\hline 32 & 30 & 4.4158 & 4.42 & 121 \\
\hline 13 & - & 4.3395 & - & 200 \\
\hline 26 & 20 & 3.4770 & 3.48 & 211 \\
\hline 15 & - & 3.1965 & - & 240 \\
\hline 30 & 30 & 3.0533 & 3.050 & 002 \\
\hline 15 & - & 2.8597 & - & 310 \\
\hline 21 & 20 & 2.8474 & 2.850 & 112 \\
\hline 100 & 100 & 2.6649 & 2.665 & 161 \\
\hline 5 & - & 2.6292 & - & 330 \\
\hline 8 & - & 2.6196 & - & 132 \\
\hline 45 & 40 & 2.6144 & 2.616 & 301 \\
\hline 18 & 25 & 2.5832 & 2.586 & 251 \\
\hline 10 & - & 2.5647 & - & 042 \\
\hline 6 & - & 2.5497 & - & 260 \\
\hline 6 & - & 2.4971 & - & 202 \\
\hline 7 & - & 2.4143 & - & 222 \\
\hline 4 & - & 2.2976 & - & 350 \\
\hline 10 & - & 2.2912 & - & 152 \\
\hline 24 & 20 & 2.1927 & 2.195 & 062 \\
\hline 11 & - & 2.1697 & - & 400 \\
\hline 4 & - & 2.1466 & - & 271 \\
\hline 4 & - & 1.9701 & - & 172 \\
\hline 5 & - & 1.9571 & - & 262 \\
\hline 9 & - & 1.7870 & - & 460 \\
\hline 4 & - & 1.7681 & - & 1101 \\
\hline 4 & - & 1.6972 & - & 192 \\
\hline 25 & 20 & 1.6776 & 1.680 & 163 \\
\hline 12 & - & 1.6697 & - & 501 \\
\hline 9 & - & 1.6647 & - & 303 \\
\hline 4 & - & 1.6566 & - & 253 \\
\hline 14 & - & 1.5755 & - & 0120 \\
\hline 51 & 45 & 1.5423 & 1.545 & 462 \\
\hline 13 & - & 1.5266 & - & 004 \\
\hline 8 & - & 1.3494 & - & 3121 \\
\hline 4 & - & 1.3208 & - & 503 \\
\hline 4 & - & 1.1608 & - & 464 \\
\hline 5 & - & 1.1459 & - & $\begin{array}{lll}5121\end{array}$ \\
\hline 4 & - & 1.1443 & - & 3123 \\
\hline 4 & - & 1.1291 & - & 165 \\
\hline
\end{tabular}

*The calculated diffraction pattern was obtained with the atom coordinates reported in Table 5 (only reflections with $I_{\text {rel }} \geq 4$ are listed; strongest experimental values in bold).

$(\lambda=0.71073 \AA)$, with $20 \mathrm{~s}$ exposure time per frame; the detector-to-sample distance was $60 \mathrm{~mm}$ (summarised in Table 4). The small fragment was mounted on a $5 \mu \mathrm{m}$ diameter carbon fibre, which was, in turn, attached to a glass rod. The diffraction intensity data were integrated and corrected for standard Lorentz polarisation factors with the software package APEX3 (Bruker AXS Inc., 2016). A total of 1317 unique reflections was collected up to $2 \theta=73.40^{\circ}$. The program SHELXL (Sheldrick, 2015) was used for the refinement of the structure. The structure solution was initiated from manganostibite structure data (Moore, 1970), and the structure solution was undertaken in the space group $\mathrm{Ibmm}$.

Though it has a nearly identical unit-cell geometry and structural topology with manganostibite (Moore, 1970), it was immediately realised that the octahedral position at the origin of the cell in manganostibite is empty in garpenbergite (see below), thus giving an overall content of $M$ cations $=6$, and not 7 as in manganostibite (cf. Table 5). 
Table 4. Crystal data and experimental conditions for the single-crystal XRD study.

\begin{tabular}{|c|c|}
\hline \multicolumn{2}{|l|}{ Crystal data } \\
\hline Ideal formula & $\mathrm{Mn}_{6} \square \mathrm{AsSbO}_{10}(\mathrm{OH})_{2}$ \\
\hline Crystal dimensions (mm) & $0.055 \times 0.045 \times 0.040$ \\
\hline Crystal system, space group & Orthorhombic, Ibmm \\
\hline Temperature $(\mathrm{K})$ & $293(2)$ \\
\hline$a, b, c(\AA)$ & 8.6790(9), 18.9057(19), 6.1066(6) \\
\hline$V\left(\AA^{3}\right)$ & $1001.99(18)$ \\
\hline$z$ & 4 \\
\hline Calculated density $\left(\mathrm{g} \cdot \mathrm{cm}^{-3}\right)$ & 4.47(1) \\
\hline$\mu\left(\mathrm{mm}^{-1}\right)$ & 11.72 \\
\hline \multicolumn{2}{|l|}{ Data collection } \\
\hline Crystal description & Brownish block \\
\hline Instrument & Bruker D8 Venture diffractomete \\
\hline Radiation type, wavelength $(\AA)$ & MoK $\alpha, 0.71073$ \\
\hline$\theta$ range $\left({ }^{\circ}\right)$ & 4.00 to 36.68 \\
\hline Absorption correction & multi-scan \\
\hline$T_{\min }, T_{\max }$ & $0.44,0.56$ \\
\hline $\begin{array}{l}\text { No. of measured, observed and } \\
\text { independent reflections }\end{array}$ & $8724,1317,957$ \\
\hline$R_{\text {int }}$ & 0.040 \\
\hline Indices range of $h, k, l$ & $-14 \rightarrow 14,-31 \rightarrow 29,-10 \rightarrow 9$ \\
\hline \multicolumn{2}{|l|}{ Refinement } \\
\hline Refinement & Full-matrix least squares on $F^{2}$ \\
\hline No. of reflections parameters, restraints & $1317,59,0$ \\
\hline$R_{1}\left[F^{2}>2 \sigma\left(F^{2}\right)\right], R_{2}$ all & $0.037,0.046$ \\
\hline GoF & 0.99 \\
\hline$w R_{1}, w R_{2}$ (all) & $0.099,0.101$ \\
\hline$\Delta \rho_{\max } \Delta \rho_{\min }\left(e^{-} \AA^{-3}\right)^{\star}$ & $2.50,-3.05$ \\
\hline
\end{tabular}

*Weighting scheme: $w=q /\left[\sigma^{2}\left(F_{0}^{2}\right)+\left(\mathrm{a}^{*} P\right)^{2}+\mathrm{b}^{*} P+\mathrm{d}+\mathrm{e}^{\star} \sin (\theta)\right]$ where $P=[\mathrm{f}$ * Maximum of $\left(0\right.$ or $\left.\left.F_{\mathrm{o}}^{2}\right)+(1-f)^{*} F_{\mathrm{c}}^{2}\right]$

The site occupation factor (s.o.f.) at the cation sites was allowed to vary ( $\mathrm{Mn} v s$. $\mathrm{Mg}$ for the $M$ sites and $\mathrm{Sb} v s$. As for the other metal sites) using scattering curves for neutral atoms taken from the International Tables for Crystallography (Wilson, 1992). The refinement of the site-occupancies gave the scattering values and the possible site populations reported in Table 6 (unconstrained refinement). At this point, taking into account the observed bond distances (Table 7), the s.o.f. occurring at the $M$ and $\mathrm{Sb} / \mathrm{As}$ sites, and the electron microprobe analysis, the following site populations were proposed: $\mathrm{Sb}=$ $\mathrm{Sb}_{1.00} ; \quad \mathrm{As}=\mathrm{As}_{0.89} \mathrm{Fe}_{0.06} \mathrm{Mn}_{0.04} \mathrm{Si}_{0.01} ; \quad M 1=\mathrm{Mn}_{0.71} \mathrm{Mg}_{0.22} \mathrm{Zn}_{0.07} ;$ $M 3=\mathrm{Mn}_{0.70} \mathrm{Mg}_{0.30} ;$ and $M 4=\mathrm{Mn}_{0.71} \mathrm{Mg}_{0.22} \mathrm{Zn}_{0.07}$ (Table 6). These proportions were then fixed in subsequent refinement cycles (see Table 6 - constrained refinement). The bond-valence sums (Table 5) indicate $\mathrm{O} 1$ as a likely hydroxyl ion in the structure. However, the individual $\mathrm{H}$ atoms could not be located in the difference-Fourier maps.
Table 6. Site-scattering values and site occupancies of garpenbergite.

\begin{tabular}{|c|c|c|c|c|c|}
\hline \multirow[b]{2}{*}{ Site } & \multicolumn{2}{|c|}{ Unconstrained refinement } & \multicolumn{2}{|c|}{ Constrained refinement } & \multirow[b]{2}{*}{$\begin{array}{c}\text { EPMA } \\
\left(e^{-}\right)\end{array}$} \\
\hline & $\begin{array}{l}\text { SCXRD } \\
\left(e^{-}\right)\end{array}$ & $\begin{array}{c}\text { Site } \\
\text { composition }\end{array}$ & $\begin{array}{c}\text { SCXRD } \\
\left(e^{-}\right)\end{array}$ & $\begin{array}{c}\text { Site } \\
\text { composition }\end{array}$ & \\
\hline sb & 51 & $\mathrm{Sb}$ & 51.00 & $\mathrm{Sb}_{0.98} \mathrm{As}_{0.02}$ & 50.64 \\
\hline As & 31.81 & $\mathrm{As}_{0.83(1)} \mathrm{Fe}_{0.1}$ & 31.82 & $\mathrm{As}_{0.87} \mathrm{Fe}_{0.06}^{3+} \mathrm{Mn}_{0.06}^{3+} \mathrm{Si}_{0.01}$ & 31.94 \\
\hline$M 1$ & 22.53 & $\mathrm{Mn}_{0.81(1)} \mathrm{Mg}_{0.19}$ & 22.52 & $\mathrm{Mn}_{0.71} \mathrm{Mg}_{0.22} \mathrm{Zn}_{0.07}$ & 22.49 \\
\hline M3 & 21.10 & $\mathrm{Mn}_{0.70(1)} \mathrm{Mg}_{0.30}$ & 21.06 & $\mathrm{Mn}_{0.70} \mathrm{Mg}_{0.30}$ & 21.10 \\
\hline M4 & 22.53 & $\mathrm{Mn}_{0.81(1)} \mathrm{Mg}_{0.19}$ & 22.48 & $\mathrm{Mn}_{0.71} \mathrm{Mg}_{0.22} \mathrm{Zn}_{0.07}$ & 22.49 \\
\hline
\end{tabular}

SCXRD - single-crystal X-ray diffraction; EPMA - electron microprobe analysis.

Table 7. Selected bond distances $(\AA)$ in the crystal structure of garpenbergite.

\begin{tabular}{llll}
\hline $\mathrm{Sb}-02$ & $1.961(4) \times 2$ & $M 3-01$ & $2.033(3) \times 2$ \\
$\mathrm{Sb}-05$ & $1.987(3) \times 4$ & $M 3-02$ & $2.135(3) \times 2$ \\
& & $M 3-05$ & $2.157(4) \times 2$ \\
$\mathrm{As}-04$ & $1.689(4) \times 2$ & & \\
$\mathrm{As}-03$ & $1.696(5) \times 2$ & $M 4-01$ & $2.152(5)$ \\
& & $M 4-03$ & $2.207(6)$ \\
$\mathrm{M} 1-02$ & $2.041(5)$ & $M 4-05$ & $2.212(2) \times 2$ \\
$\mathrm{M} 1-05$ & $2.042(3) \times 2$ & $M 4-04$ & $2.251(3) \times 2$ \\
$\mathrm{M1}-03$ & $2.097(5)$ & & \\
\hline
\end{tabular}

Table 8. Bond-valence sums calculated with the site populations reported in Table 5 and according to the parameters of Brese and O'Keeffe (1991) for all the atoms but $\mathrm{Sb}$, which was modelled with the parameters of Mills et al. (2009).

\begin{tabular}{lcccccc}
\hline & \multicolumn{1}{c}{ Sb } & As & \multicolumn{1}{c}{$M 1$} & \multicolumn{1}{c}{$M 3$} & \multicolumn{1}{c}{$M 4$} & $\Sigma 0$ \\
\hline O1 & & & & $0.455^{\times 2 \downarrow}$ & 0.370 & 1.280 \\
O2 & $0.876^{\times 2 \downarrow}$ & & 0.513 & $0.331^{\times 2 \downarrow}$ & & 2.051 \\
O3 & & $1.151^{\times 2 \downarrow}$ & 0.443 & & 0.339 & 1.933 \\
O4 & & $1.208^{\times 2 \downarrow}$ & & & $0.293^{\times 2 \downarrow}$ & 1.794 \\
O5 & $0.824^{\times 4 \downarrow}$ & & $0.506^{\times 2 \downarrow}$ & $0.341^{\times 2 \downarrow}$ & $0.315^{\times 2 \downarrow}$ & 1.986 \\
$\Sigma$ & 5.048 & 4.718 & 1.968 & 2.254 & 1.925 & \\
\hline
\end{tabular}

The crystal structure refinement finally converged to $R_{1}=3.7 \%$ for 957 reflections with $F>4 \sigma(F)$ and 53 parameters. The experimental details and all $R$ indices obtained are summarised in Table 4. Fractional atomic coordinates and isotropic displacement parameters are reported in Table 5 . Bond distances are given in Table 7, and calculated bond-valence sums in Table 8. The crystallographic information file has been deposited with the

Table 5. Atoms, Wyckoff positions (Wyck.), mean electron numbers, inferred site populations, fractional coordinates of atoms, and isotropic displacement parameters in the structure of garpenbergite.

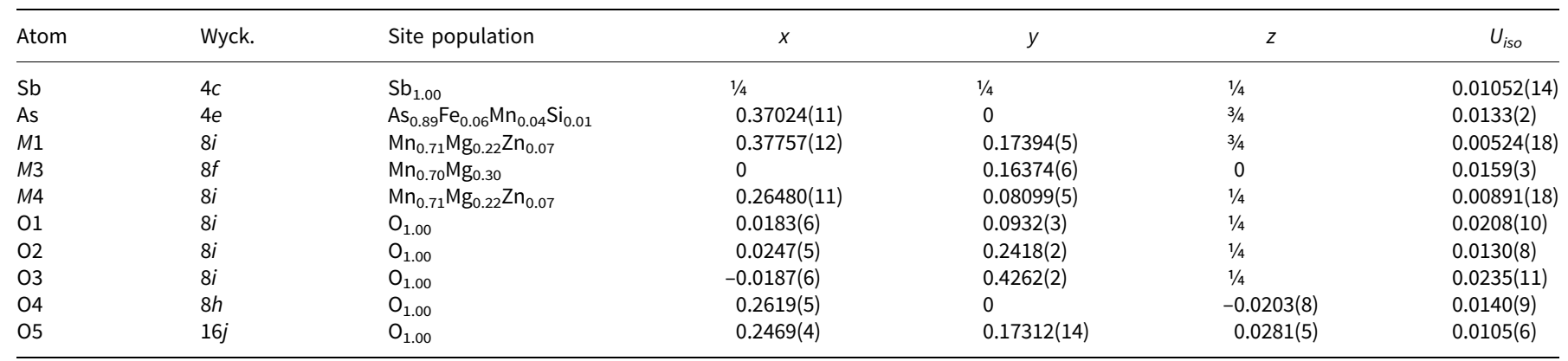


Principal Editor of Mineralogical Magazine and is available as Supplementary material (see below).

\section{Description of the crystal structure}

The crystal structure of garpenbergite (Fig. 3a) consists of a cubic close-packed array of oxygen atoms with layers stacked along [130], with cations occupying tetrahedral and octahedral voids in a spinel-like arrangement. The heteropolyhedral framework consists of chains of edge-sharing $M 4$ and $\mathrm{Sb}$ octahedra along the $b$ axis, connected by strips of edge-sharing M3 octahedra stretching along c. $M 1(\times 2)$ and As tetrahedra sharing corners with each other in triplets, and with adjacent octahedra. The calculated bond-valance sums (Table 8) for cation sites are in good agreement with the expected formal charges of the main ionic species, $\mathrm{Mn}^{2+}, \mathrm{As}^{5+}$ and $\mathrm{Sb}^{5+}$. The higher value obtained for the $M 3$ polyhedron is probably related to accumulation of $\mathrm{Mn}^{3+}$ at that site, along with some enrichment of $\mathrm{Mg}$. The octahedrally coordinated M2 site, filled with $\mathrm{Mn}^{2+}$ in manganostibite, is vacant in garpenbergite (Fig. 3b). Charge-compensation is achieved by incorporation of protons in the structure. This is most likely to occur close to the octahedral vacancy, in order to obtain a favourable electrostatic situation locally. As $\mathrm{O} 1$ and $\mathrm{O} 4$ are the most undersaturated anions in the structure (1.28 and 1.79 valence units, respectively), we conclude that protonation occurs along edges of the otherwise empty $M 2$ octahedron. The hydroxyl-stretching bands around $3600 \mathrm{~cm}^{-1}$ suggest $\mathrm{O} \cdots \mathrm{O}$ contacts $>3.0 \AA$ (Libowitzky, 1999), in agreement with O1-O4 distances of 3.2 and $3.3 \AA$ obtained for the present crystal structure.

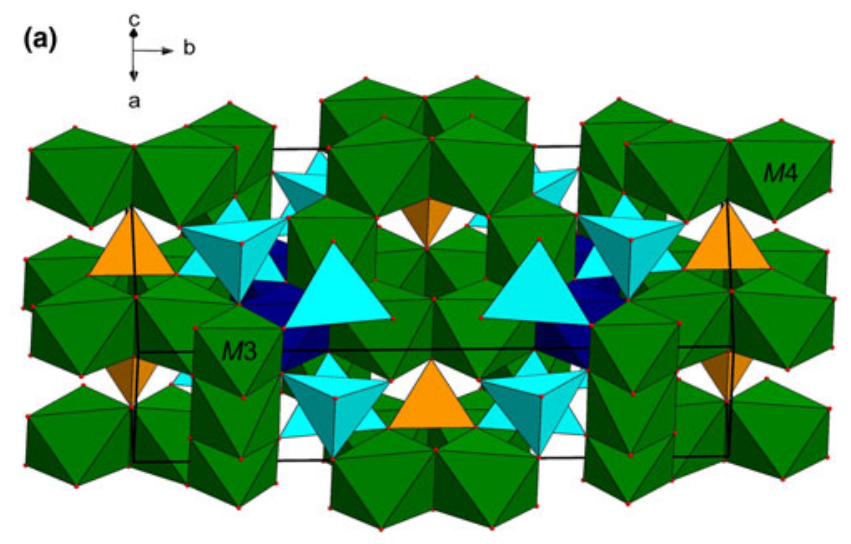

(b)
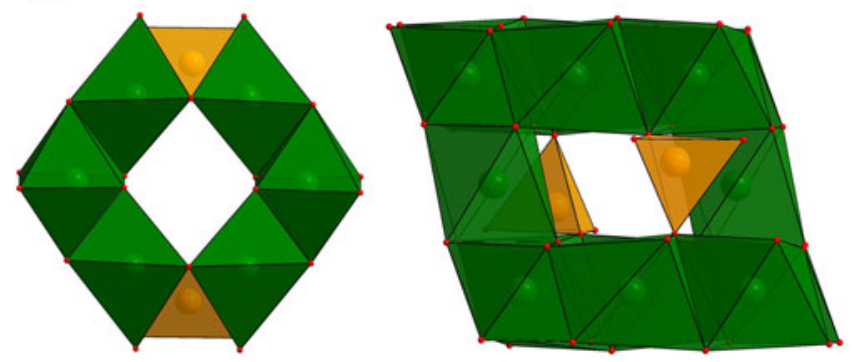

Fig. 3. (a) The crystal structure of garpenbergite. The unit cell and the orientation of the structure are outlined. (b) Structural sketches highlighting the empty $M 2$ site of garpenbergite, which is occupied by $\mathrm{Mn}$ in manganostibite (Moore, 1970). Orange and light blue tetrahedra indicate As and $M 1$ sites. Dark blue and green octahedra refer to Sb, M3 and M4 sites, respectively. Red spheres indicate oxygen atoms.

\section{Concluding remarks}

Relation with other mineral species and synthetic compounds

The structural topology of garpenbergite is nearly the same as for manganostibite (Moore, 1970). The new mineral is derived from manganostibite via the coupled ion exchange $\mathrm{Mn}^{2+}+2 \mathrm{O}^{2-} \rightarrow$ $\square+2(\mathrm{OH})^{-}$, or in vector notation, $\mathrm{Mn}^{2+}\left(\square \mathrm{H}_{2}^{+}\right)_{-1}$, which leaves the space-group symmetry invariant. Notably, $\mathrm{Ibmm}$ is one of the orthorhombic subgroups of the $F d \overline{3} m$ spinel space group (Moore and Smith, 1969).

Garpenbergite fits in the Strunz group 4.CA rather than 4.BA (with manganostibite; Strunz and Nickel, 2001) due to a different metal:oxygen ratio (2:3 vs. 3:4). The synthetic orthorhombic phases denoted 'spinelloid phase II' (e.g. $\mathrm{Ni}_{4} \mathrm{Al}_{4} \mathrm{SiO}_{12}, \mathrm{Ma}, 1974$; $\mathrm{Fe}_{7.71} \mathrm{Si}_{1.29} \mathrm{O}_{12}$, Angel and Woodland, 1998) and $\mathrm{Co}_{7} \mathrm{As}_{2} \mathrm{O}_{12}$ (Barbier, 1997) have a close structural kinship with both manganostibite and garpenbergite. Moreover, the nesosilicate gerstmannite (Moore and Araki, 1977a) has a metrically similar unit cell, but crystallises in the space-group $\mathrm{Bbcm}$. Somewhat related are also the $\mathrm{OH}$-bearing arsenosilicates holdenite (Moore and Araki, 1977b) and kolicite (Peacor, 1980). Note that the overgrowth of filipstadite on garpenbergite is probably epitaxial; both minerals exhibit the spinel-structure theme with $\mathrm{Sb}^{5+}$ ions ordered at octahedral sites, and the unit-cell parameter $a$ of garpenbergite is $1 / 3 \times a$ of filipstadite ( $26 \AA$; Bonazzi et al., 2013).

The handbook formula for garpenbergite might be written in simplified form as $\mathrm{Mn}_{6} \mathrm{AsSbO}_{10}(\mathrm{OH})_{2}$, but at this instance, we prefer $\mathrm{Mn}_{6} \square \mathrm{AsSbO}_{10}(\mathrm{OH})_{2}$ to emphasise the close relationship with manganostibite. If the essential constituents are grouped after coordination environment $(M=$ octahedral and $T=$ tetrahedral), the general formula is $M_{6} \mathrm{O}_{2} T_{3} \mathrm{O}_{10}$ for manganostibite and $M_{5} \square(\mathrm{OH})_{2} T_{3} \mathrm{O}_{10}$ for garpenbergite. These minerals are part of a homologous series formalised as $M_{2 n} \varphi_{n-1} T_{n} \mathrm{O}_{3 n+1}$, where $n=1$ for spinel and $n=3$ for manganostibite/garpenbergite, and with $\varphi$ representing $\mathrm{O}^{2-}$ or $\mathrm{OH}^{-}$.

\section{Crystal chemistry}

There is partial replacement of $\mathrm{Mn}$ by $\mathrm{Mg}$ and $\mathrm{Zn}$ in the ideal end-member formula of garpenbergite, which is apparent in the chemical point analytical data for the slightly inhomogeneous crystal (Fig. 4). It has a significantly higher $\mathrm{Mg}$ concentration than that known for manganostibite (1.0-2.9 wt.\% $\mathrm{MgO}$; Holtstam et al., 1998), but $\mathrm{Mg}^{2+}$ is not strongly ordered at any particular site in the structure. Garpenbergite is also comparably enriched in $\mathrm{Zn}$; this element ought to be concentrated at the tetrahedral (M1) site. The M3 octahedron is axially compressed, with two short and four long $M-\mathrm{O}$ distances. This coordination environment is thus favourable for $\mathrm{Mn}^{3+}$ due to the Jahn-Teller interaction of the $d^{4}$ ion.

The $\mathrm{Sb}$ content in garpenbergite is close to the nominal value of $1 \mathrm{apfu}$; the situation is invariably the same for different samples of manganostibite (Holtstam et al., 1998). In contrast, the As site is hosting additional cations, like $\mathrm{Si}, \mathrm{Fe}^{3+}$ and probably $\mathrm{Mn}^{3+}$. This is not unexpected, since manganostibite is shown to contain up to $0.48 \mathrm{Si}$ apfu (Holtstam et al., 1998) and explained by considerations of electrostatic bond valances for the ideal (non-substituted) structure (Moore 1970). The $\mathrm{AsO}_{4}$ tetrahedron may seem too small to accommodate the trivalent cations; however, limited $\mathrm{Fe}^{3+}$-for- $\mathrm{As}^{5+}$ substitution is still indicated by chemical variations in the crystal (Fig. 5). 

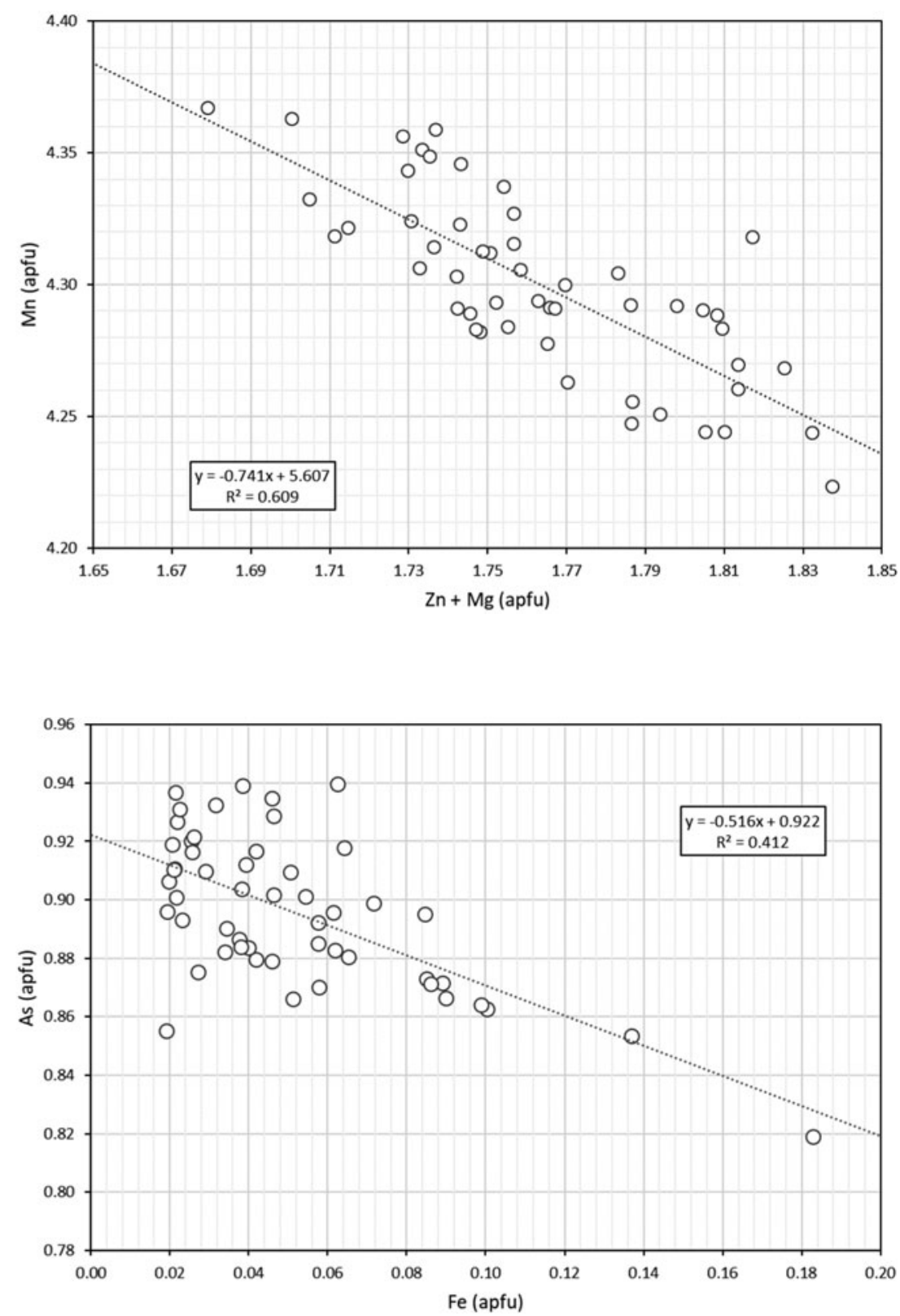

Fig. 4. Compositional variations in garpenbergite in terms of $\mathrm{Mn}$ vs. $(Z n+M g)$. The stippled line is the linear regression curve.

Fig. 5. Compositional variations in garpenbergite in terms of As and $\mathrm{Fe}^{3+}$.

The mechanism introducing $\mathrm{H}^{+}$in a spinel-like atomic arrangement invoked here is not unique; it is found for, e.g. highpressure variants of $\mathrm{MgAl}_{2} \mathrm{O}_{4}$ spinel (Bromiley et al., 2010) and related compounds, like ringwoodite $(n=1)$ (Grüninger et al., 2020) and wadsleyite $(n=2)$ (Deon et al., 2010), and is coupled to cation vacancies at, most frequently, octahedral sites in those structures. For garpenbergite, high-pressure conditions are not inferred, but a high- $f_{\mathrm{H}_{2} \mathrm{O}}$ environment of formation is indicated by the close association with the strongly hydrous mineral carlfrancisite. Notably, carlfrancisite from Garpenberg is very similar in composition to the holotype specimen from Kombat, Namibia (Hawthorne, 2018). We do not, however, expect to find the same paragenesis as described here at Kombat, because of insignificant $\mathrm{Sb}$ concentration in the ore lithologies there.

Acknowledgements. We thank Franz Vyskytensky, Kopparberg, for providing specimens from the Garpenberg deposit over the years. Oona Appelt (GFZ) is thanked for her support with the electron microprobe work.
Reviews by two anonymous reviewers and Structural Editor Peter Leverett improved the paper.

Supplementary material. To view supplementary material for this article, please visit https://doi.org/10.1180/mgm.2022.6

\section{References}

Allen R., Bull S., Ripa M. and Jonsson R. (2003) Regional stratigraphy, basin evolution, and the setting of stratabound $\mathrm{Zn}-\mathrm{Pb}-\mathrm{Cu}-\mathrm{Ag}-\mathrm{Au}$ deposits in Bergslagen, Sweden. Sveriges geologiska undersökning, FoU-rapport, 3, 1-99. Angel R.J. and Woodland A.B. (1998) Crystal structure of spinelloid II in the system $\mathrm{Fe}_{3} \mathrm{O}_{4}-\mathrm{Fe}_{2} \mathrm{SiO}_{4}$. European Journal of Mineralogy, 10, 607-612.

Barbier J. (1997) $\mathrm{Co}_{7} \mathrm{As}_{2} \mathrm{O}_{12}$ : a new cobalt arsenate with a spinelloid-type structure. Zeitschrift für Kristallographie, 212, 445-449.

Bernardini S., Bellatreccia F., Della Ventura G. and Sodo, A. (2021) A reliable method for determining the oxidation state of manganese at the microscale in Mn oxides via Raman spectroscopy. Geostandards and Geoanalytical Research, 45, 223-244. 
Bindler R., Karlsson J., Rydberg J., Karlsson B., Nilsson L.B., Biester H. and Segerström U. (2017) Copper-ore mining in Sweden since the pre-Roman Iron Age: lake-sediment evidence of human activities at the Garpenberg ore field since 375 BCE. Journal of Archaeological Science: Reports, 12, 99-108.

Bolin N.J., Brodin P. and Lampinen P. (2003) Garpenberg - an old concentrator at peak performance. Minerals Engineering, 16, 1225-1229.

Bonazzi P., Chelazzi L. and Bindi L. (2013) Superstructure, crystal chemistry, and cation distribution in filipstadite, a $\mathrm{Sb}^{5+}$-bearing, spinel-related mineral. American Mineralogist, 98, 361-366.

Brese N.E. and O'Keeffe M. (1991) Bond-valence parameters for solids. Acta Crystallographica, B47, 192-197.

Bromiley G.D., Nestola F., Redfern S.A. and Zhang M. (2010) Water incorporation in synthetic and natural $\mathrm{MgAl}_{2} \mathrm{O}_{4}$ spinel. Geochimica et Cosmochimica Acta, 74, 705-718.

Bruker AXS Inc. (2016) APEX3, SAINT and SADABS. Bruker AXS Inc., Madison, Wisconsin, USA.

Carlberg J.O. (1879) Historiskt sammandrag om svenska bergverkens uppkomst och utveckling, samt grufvelagstifningen etc. K.L. Beckmann, Stockholm, $664 \mathrm{pp}$.

Deon F., Koch-Müller M., Rhede D., Gottschalk M., Wirth R. and Thomas S.M. (2010) Location and quantification of hydroxyl in wadsleyite: New insights. American Mineralogist, 95, 312-322.

Dunn P.J. (1995) Franklin and Sterling Hill, New Jersey: The World's most Magnificent Mineral Deposits. The Franklin-Ogdensburg Mineralogical Society, Franklin, New Jersey, USA, 755 pp.

Eriksson L. and Kalinowski M.P. (2001) $\mathrm{Mn}_{1-x} \mathrm{Fe}_{x} \mathrm{~S}$, an example of an antiwurtzite structure. Acta Crystallographica, E57, i92-i93.

Grüninger H., Liu Z., Brauckmann J.O., Fei H., Boffa Ballaran T., Martin T., Siegel R., Kentgens A.P.M, Frost D.J. and Senker J. (2020) Hydroxyl defects and oxide vacancies within ringwoodite-toward understanding the defect chemistry of spinel-type oxides. The Journal of Physical Chemistry C, 124, 12001-12009.

Guillén-Bonilla A., Rodríguez-Betancourtt V.M., Flores-Martínez M., Blanco-Alonso O., Reyes-Gómez J., Gildo-Ortiz L. and Guillén-Bonilla, H. (2014) Dynamic response of $\mathrm{CoSb}_{2} \mathrm{O}_{6}$ trirutile-type oxides in a $\mathrm{CO}_{2}$ atmosphere at low-temperatures. Sensors, 14, 15802-15814.

Hawthorne F.C. (2018) Long-range and short-range cation order in the crystal structures of carlfrancisite and mcgovernite. Mineralogical Magazine, 82, $1101-1118$.

Holtstam D. (2002) New occurrences of willemite-franklinite assemblages in Bergslagen, central Sweden. European Journal of Mineralogy, 14, 621-626.

Holtstam, D. (2021) Raman spectroscopy as a tool in mineral discoveries. $9^{\text {th }}$ International Conference Mineralogy and Museums, Extended abstracts, Sofia, Bulgaria, p. 50.

Holtstam D. and Langhof J. (editors) (1999) Langban. The Mines, their Minerals, Geology and Explorers. Swedish Museum of Natural History and Raster Förlag, Stockholm, $215 \mathrm{pp}$.

Holtstam D. and Mansfeld J. (2001) Origin of a carbonate-hosted Fe-Mn$(\mathrm{Ba}-\mathrm{As}-\mathrm{Pb}-\mathrm{Sb}-\mathrm{W})$ deposit of Långban-type in Central Sweden. Mineralium Deposita, 36, 641-657.

Holtstam D., Nysten P. and Gatedal K. (1998) Parageneses and compositional variations of $\mathrm{Sb}$ oxyminerals from Långban-type deposits in Värmland, Sweden. Mineralogical Magazine, 62, 395-407.

Holtstam D., Gatedal K., Söderberg K. and Norrestam R. (2001) Rinmanite, $\mathrm{Zn}_{2} \mathrm{Sb}_{2} \mathrm{Mg}_{2} \mathrm{Fe}_{4} \mathrm{O}_{14}(\mathrm{OH})_{2}$, a new mineral species with a nolanite-type structure from the Garpenberg Norra mine, Dalarna, Sweden. The Canadian Mineralogist, 39, 1675-1683.

Holtstam D., Bindi L., Förster H.-J., Karlsson A. and Gatedal K. (2021) Garpenbergite, IMA 2020-099. CNMNC Newsletter 61. Mineralogical Magazine, 85, https://doi.org/10.1180/mgm.2021.48

Igelström L.J. (1884) Manganostibiite [sic!], nouveau minéral de Nordmark, Wermland (Suède). Bulletin de Minéralogie, 7, 120-121.
Jambor J.L. and Vaughan D.J. (editors) (1990) Advanced Microscopic Studies of Ore Minerals. Mineralogical Association of Canada, Nepean, Ontario, Canada, 426 pp.

Jansson N.F. and Allen R.L. (2011) Timing of volcanism, hydrothermal alteration and ore formation at Garpenberg, Bergslagen, Sweden.GFF, 133, 3-18.

Kolitsch U. and Holtstam D. (2002) Barysilite from Garpenberg Norra, Dalarna, Sweden: occurrence and crystal structure refinement. Mineralogical Magazine, 66, 353-363.

Libowitzky E (1999) Correlation of O-H stretching frequencies and $\mathrm{O}-\mathrm{H} \cdots \mathrm{O}$ hydrogen bond lengths in minerals. Monatshefte für Chemie, 130, 1047-1059.

Ma C.B. (1974) New orthorhombic phases on the join $\mathrm{NiAl}_{2} \mathrm{O}_{4}$ (spinel ana$\log$ ) $-\mathrm{Ni}_{2} \mathrm{SiO}_{4}$ (olivine analog): Stability and implications to mantle mineralogy. Contributions to Mineralogy and Petrology, 45, 257-279.

Mandarino J.A. (1981) The Gladstone-Dale relationship; Part IV, The compatibility concept and its application. The Canadian Mineralogist, 19, 441-450.

Mills S.J., Christy A.G., Chen E.C.-C. and Raudsepp M. (2009) Revised values of the bond valence parameters for ${ }^{[6]} \mathrm{Sb}(\mathrm{V})--\mathrm{O}$ and ${ }^{[3-11]} \mathrm{Sb}(\mathrm{III})--\mathrm{O}$. Zeitschrift für Kristallographie, 224, 423-431.

Moore P.B. (1970) Manganostibite: A novel cubic close-packed structure type. American Mineralogist, 55, 1489-1499.

Moore P.B. and Araki T. (1977a) Gerstmannite, a new zinc silicate mineral and a novel cubic close-packed oxide structure. American Mineralogist, 62, 51-59.

Moore P.B. and Araki T. (1977b) Holdenite, a novel cubic close-packed structure. American Mineralogist, 62, 513-521.

Moore P.B. and Smith J.V. (1969) High pressure modification of $\mathrm{Mg}_{2} \mathrm{SiO}_{4}$ : Crystal structure and crystallochemical and geophysical implications. Nature, 221, 653-655.

Myneni S.C., Traina S.J., Waychunas G.A. and Logan T.J. (1998) Experimental and theoretical vibrational spectroscopic evaluation of arsenate coordination in aqueous solutions, solids, and at mineral-water interfaces. Geochimica et Cosmochimica Acta, 62, 3285-3300.

Nysten P. (2003) Yeatmanite and magnussonite from the Garpenberg Norra mine, Bergslagen ore province, Sweden. The Canadian Mineralogist, 41, 201-206.

Peacor D.R. (1980) The crystal structure of kolicite, $\mathrm{Mn}_{7}(\mathrm{OH})_{4}\left[\mathrm{As}_{2} \mathrm{Zn}_{4} \mathrm{Si}_{2} \mathrm{O}_{16}(\mathrm{OH})_{4}\right]$. American Mineralogist, 65, 483-487.

Peck W.H., Volkert R.A., Mansur A.T. and Doverspike B.A. (2009) Stable isotope and petrologic evidence for the origin of regional marble-hosted magnetite deposits and the zinc deposits at Franklin and Sterling Hill, New Jersey Highlands, United States. Economic Geology, 104, 1037-1054.

Sheldrick G.M. (2015) Crystal structure refinement with SHELXL, Acta Crystallographica, C71, 3-8.

Stephens M.B. and Jansson N.F. (2020) Paleoproterozoic (1.9-1.8 Ga) syn-orogenic magmatism, sedimentation and mineralization in the Bergslagen lithotectonic unit, Svecokarelian orogen. Pp. 155-206 in: Sweden: Lithotectonic Framework, Tectonic Evolution and Mineral Resources (Stephens M.B. and Bergman Weihed J., editors). Geological Society, London, Memoirs, 50.

Strunz H. and Nickel E.H. (2001) Strunz Mineralogical Tables: Chemical-Structural Mineral Classification System (9th edition). Schweizerbart, Stuttgart, Germany, 870 pp.

Tiu G., Jansson N., Wanhainen C., Ghorbani Y. and Lilja L. (2021) Ore mineralogy and trace element (re)distribution at the metamorphosed Lappberget $\mathrm{Zn}-\mathrm{Pb}-\mathrm{Ag}-(\mathrm{Cu}-\mathrm{Au})$ deposit, Garpenberg, Sweden. Ore Geology Reviews, 135, 104223.

Vivallo W. (1985) The geology and genesis of the Proterozoic massive sulfide deposit at Garpenberg, central Sweden. Economic Geology, 80, 17-32.

Wilson A.J.C. (editor) (1992) International Tables for Crystallography, Volume C: Mathematical, Physical and Chemical Tables. Kluwer Academic, Dordrecht, The Netherlands. 